\title{
Main problems of development of nut-fruited crops' production
}

\author{
H. Satina, \\ Senior Researcher
}

Institute of Horticulture of NAAS

The purpose. To mark out a circle of problems and to determine the causes constraining development in Ukraine of industrial production of walnuts. Methods. Dialectic, abstract-logical, statistical, analysis and synthesis, balance. Results. Probes have shown series of the causes and conditions restraining productions of walnuts. The basic problems are as follows: low standards of nutrition in the country, absence of effective mechanism of development of the branch. Conclusions. Consumer worth of walnuts, weighable foreign demand and presence of competitive advantages of our country induces to overcoming the determined balancers and dilating of domestic production.

Key words: nut-fruited crops' production, development, problems, factors of constraining.

Popularity nuts in the consumer market due to their nutritional, therapeutic and economic value. Specifically, walnuts called "tree - plant" because from different parts are made: flour, halvah, oil, milk, canned foods, beverages, pharmaceuticals, food, oils, paints, varnishes, decorative items, furniture. However, the most valuable is the use of fresh fruits because they are part of the essential amino acids and rare compounds that increase the body's resistance to radiation pollution, promote excretion of carcinogenic substances and hinder the development of cancer [3]. The successful combination of fat, protein, carbohydrates, micro and macro elements promotes therapeutic effect in cardiovascular disorders, atherosclerosis, diabetes, liver disorders, metabolism, and so on.

That is why in many countries widely promoted the use of nuts. Changing lifestyles and good nutrition provide significant therapeutic and preventive effect appears on the level of the organism in 1-2 years, and among the population (increasing life expectancy, reducing mortality) - through 10 years [1]. That's why nuts are a mandatory part of many diets. And in the world there is a gradual increase use of nuts in food: in $2005-1,7,2009-2,2$, $2013-2,3 \mathrm{~kg}$ of fruit per person per year [4,9]. But in Ukraine consumption of nuts cannot be considered satisfactory. On the one hand, the recommended rates are higher than the actual: physiologically optimal $-3,6 \mathrm{~kg}$ of fruit per year, rational $-1,5$. On the other hand, nuts consumption in countries with high culture of food is higher: Greece $-10,9$ kg, Turkey $-6,7$, Italy $-7,9$ France -4.1 .

Note that Ukraine accumulates competitive advantages in developing large-scale production of walnuts and hazelnuts: favorable agro-climatic zones, the high-quality varieties, good geographical location to major customers, availability of land and labor resources, traditional cultivation [2, 6-7]. However, in our country rather slow recovery dynamics nut production, and even if meaningful external demand. This encourages understanding of the causes and circumstances of deterring the industry development.

The purpose of research. The task of ensuring proper consumer market in nuts necessitates a clear outline of problems of the domestic industry.

The methodological base of research served as a dialectical method of knowledge, analysis and synthesis, balance, system synthesis.

The research results confirm a number of problems in the development of the consumer market and industrial sector, the main ones are as follows.

Low food culture. Against the background of high production rates and nut export consumption in Ukraine is extremely small. The highest was recorded in $2005-1,4 \mathrm{~kg}$ per capita per year, and the lowest in $2010-0,3 \mathrm{~kg}$. In recent years, urban residents consumed an average of $1,1 \mathrm{~kg}$, and the rural population $-0,7$. For comparison, according to the FAO in 2013, one person in the world consumed about 2,3 kg of nuts, especially in the EU countries $-4,8 \mathrm{~kg}$, in the countries of low-income and food deficit $-1,6 \mathrm{~kg}$, and in the least developed $-0,8 \mathrm{~kg}$ (figure 1). 


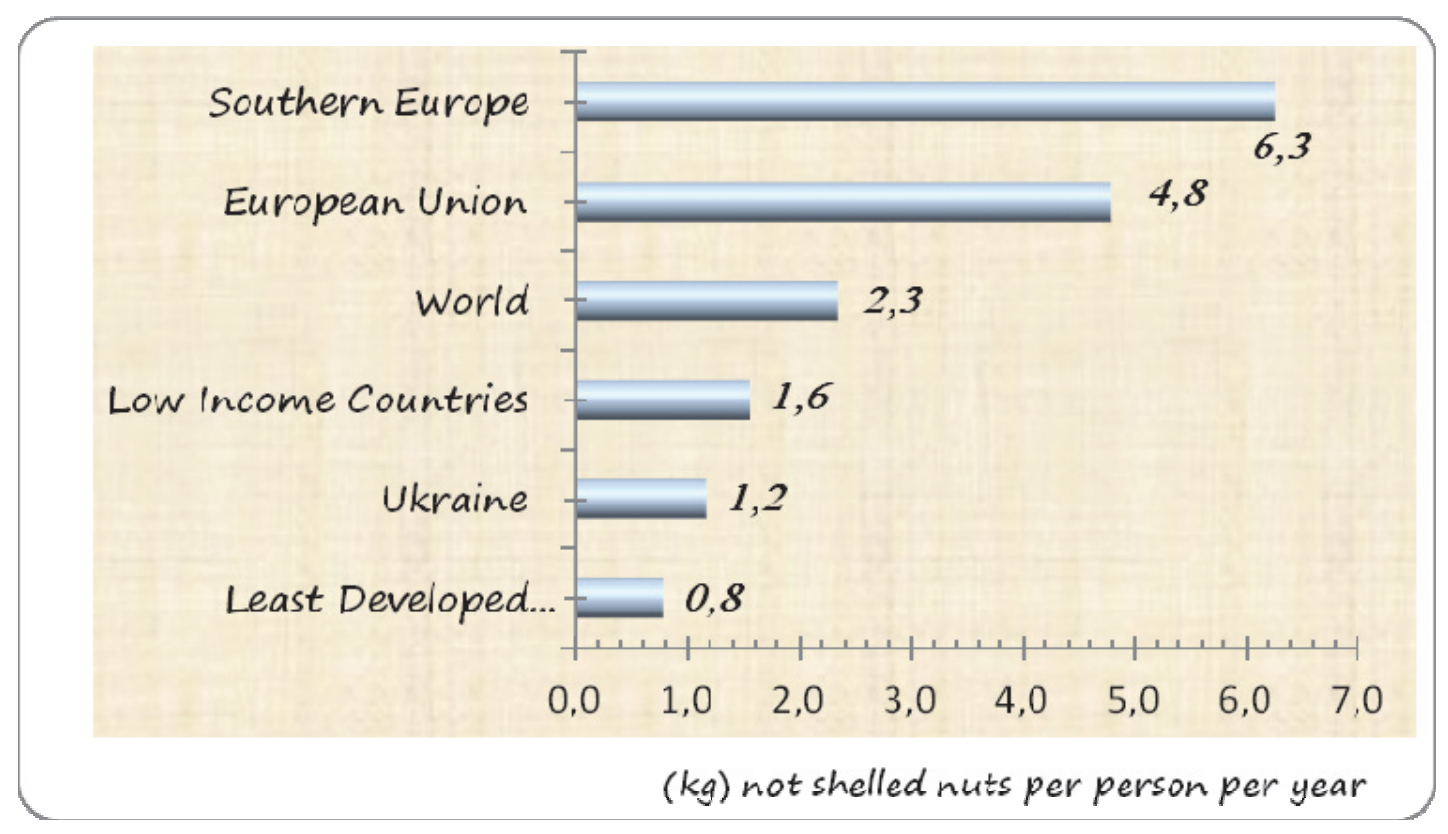

Figure 1. Consumption of fruits of treenut species in 2013, kg/person

Low solvency. The main reason for poor nuts consumption in Ukraine is the low living standards. This is manifested in the tendency of rural households to maximize the realization of the harvested crop in favor of increasing incomes (figure 2). As a result, use their own production of nuts reduced by $78 \%$ (2013-15 years). In addition, the urban population is not solvent enough to purchase nutty products in the proper quantities: according to estimates, the shortage of funds is about $400 \mathrm{UAH}$ per person per year.

Product distribution disparities. Due to the significant supply shortage of nuts in the world, Ukraine tends to maximize the extraction of whole nuts and kernels for export (55-97\% of the harvested crop). But a lot of nuts come to the domestic market from abroad as part of the finished product, after deep processing and using food substitutes, concentrates and dyes. Despite the nutritional value of nuts and negative demographic processes in the country, it is advisable to stimulate the redistribution of grown products in favor of growing domestic consumption. Such a policy with respect to its own consumer is practiced in a number of countries - along with the development of exports they are concerned about saturation of the domestic market. For example, in 2011, Iran harvested $13,0 \mathrm{~kg}$ of nuts per person and 11,2 kg was consumed, in Turkey - 11,7 and 6,9 $\mathrm{kg}$ respectively, in China ( $23 \%$ of world charges) $-2,6$ and $2,5 \mathrm{~kg}$. 


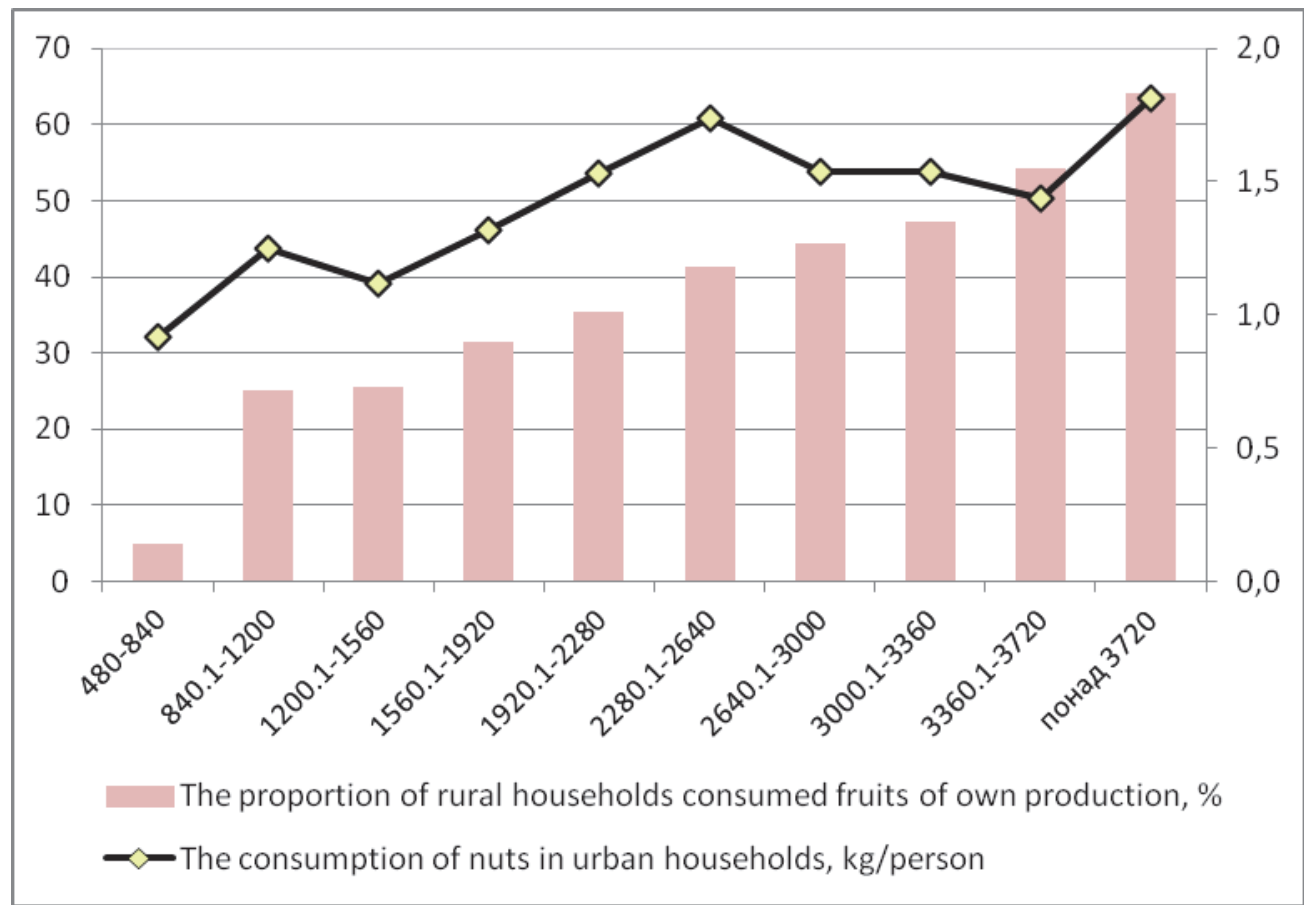

Figure 2. Consumption of nuts in Ukrainian households depending on the size of average equivalent income in 2015

Concentration of production in the household sector. The production of nuts there is technologically simple, does not require significant labor and time, and for high demand for nuts is highly profitable. However, given the specifics of the activities of these farms, the concentration in them of orchards (95,1\% of areas) and food resources $(99,8 \%$ of fees) is excessive. Nuts are delivered to the market in small lots, spontaneously, which leads to difficulty in harvesting fruits, inhibits the development of deep processing and narrows the range of final products. Along with this, it should be noted a number of chronic problems in this sector of commodity production - a hybrid variety of trees and the obsolete fruit-bearing plantations ( $91 \%$ of the examined plants are older than 40 years).

Production of raw materials. The arrangement of orchards in households and the methods of obtaining fruits are the main reason of produce the raw material. The product is formed from the sort mix, with non-observance of technologies for bringing nuts into the conditioning state. Often whole fruits and kernels do not meet the interstate (GOST 16830-71, GOST 16831-71, GOST 16832-71, GOST 16833-71, GOST 16834-81, GOST 16835-81) and international trade standards (DDP-01 DPP-02 DDP-03 DDP-04 DDP-05 DDP-06 DDP-18, DDP-21). Overcoming this problem is possible by spreading varietal plantations, the development of cooperative movement with nut processing and the introduction of state quality standards. Standards should regulate norms that strengthen the control over the ecological purity of the final product, exclude and make it impossible to use a threat to the consumer's health of technologies, their individual elements and components.

The slow development of the industrial sector. Over the past 10 years, Ukraine has laid about 3,0 thousand hectares of industrial nut-bearing orchards: 5-10 thousand tons of nuts can be expected from them with full fruiting 15-35 center per ha. This is clearly not enough to meet consumer demand, because such a crop can provide only $2 \%$ of domestic needs. The experience of many countries shows that it is possible to significantly increase gross fees and produce quality by creating industrial orchards $[6,8,10]$. Thus, in neighboring Moldova since 2005, it has been possible to expand walnut industrial areas to 14,000 hectares and increase the yield to 14,000 tons of nuts. USA, which do not have natural plantations of this culture, during the 20th century managed to create an entire industry. In 2013, this country reached such indicators: the area of intensive orchards $-113,1$ thousand hectares, the gross harvest -420 thousand tons, $1 / 2$ of the whole nut exports in world and more than $1 / 3$ - the extracted nuclei. However, the absolute leader is China: for 5 years the area of nut-bearing orchards there grew by 165 thousand hectares, and gross fees from 2,7 to 3,6 million tons of nut. In Ukraine, however, industrial culture is still underdeveloped. 
Unstable development of nursery. In Ukraine from 2006 to 2015 grew 519,4 thousand units of nut planting material: walnut $-457,6$ and almonds $-61,8$. At first, farms preferred seed reproduction, and the proportion of seedlings thus obtained was more than $80 \%$. But since 2008 , active vegetative propagation of varieties has begun. And for several years the number of grown varietal plants grew by 6,2 times and made a walnut $-85,8$, almonds 16,1 thousand pieces. However, the stability in nursery farming was not achieved. Production volumes were gradually curtailed to 20,7 thousand plants and only in 2015 increased again 6 times - to 124,6 thousand units. Let's notice, constantly nursery of a walnut in Ukraine is engaged only 3 companies, and any has not organized industrial reproduction hazelnut.

Zone spraying of industrial orchards. According to the aggregate of agroclimatic conditions, the best regions for the location of industrial walnut gardens are Transnistria, Prykarpattya and Transcarpathia, which form a zone of highly efficient production [3,5]. However, new plantings are often laid without taking into account the suitability of the soil-climatic characteristics of the terrain. This is evidenced by the scattered nature of industrial orchards in zones and regions (figure 3). During 2011-15 years the largest share of gardens is laid in the south of the country (31\%), in the central and eastern Forest-steppe (36\%). Among the regions the Dnipropetrovs'k (616 hectares), Nikolaev (414 hectares) and Cherkassy (310 ha) occupy the first positions. But these zones are characterized by moderate efficiency in the industrial walnuts cultivation.

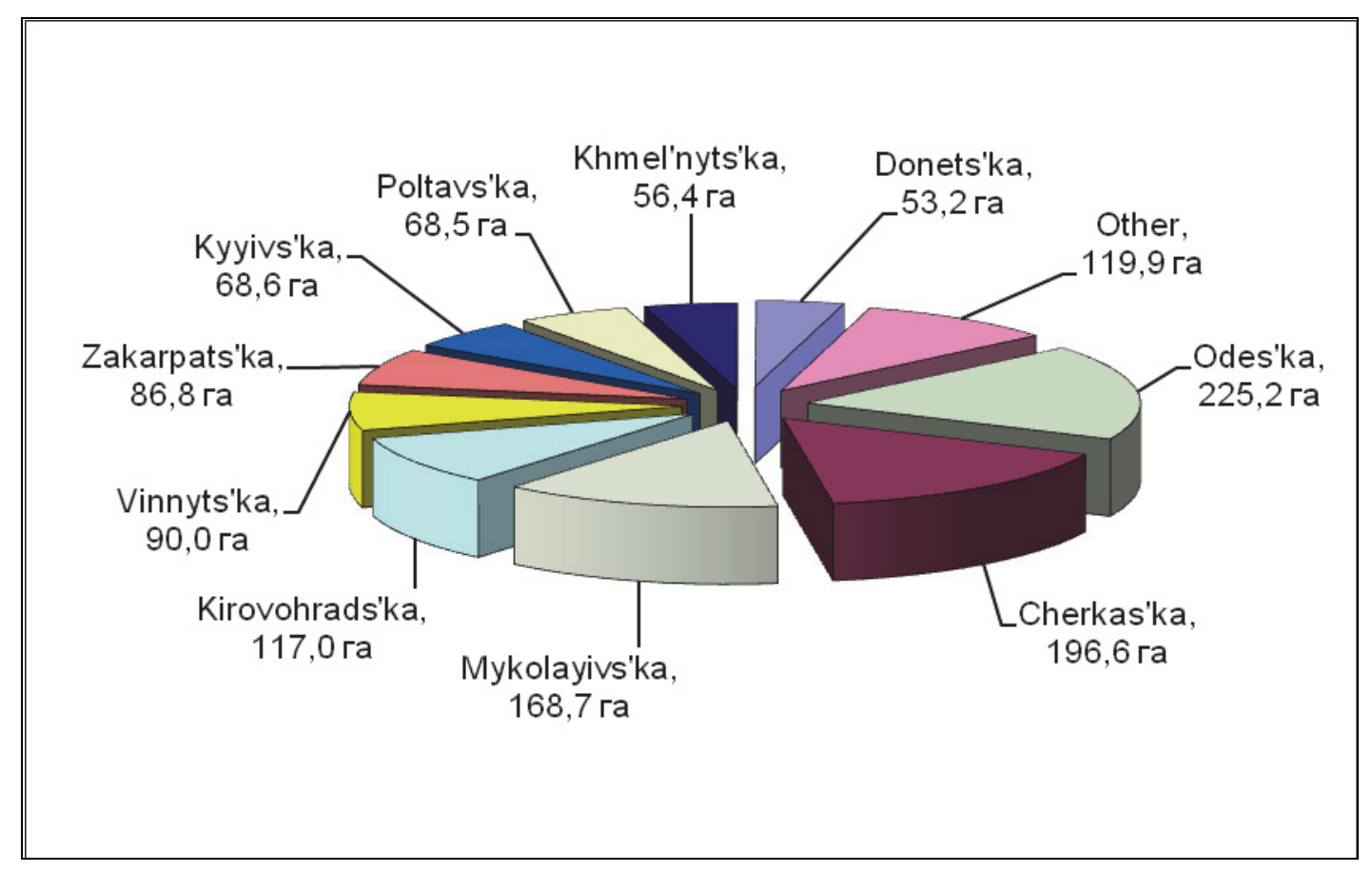

Picture 3. Zonal distribution of laying nut plantations in Ukraine, ha

High investment threshold. Calculations indicate a high capital intensity for the creation of industrial orchards. On 1 January 2017 the book value of 1 hectare of walnut according to the standard technology (scheme 10x8, without irrigation) reaches 346,3 thousand $\mathrm{UAH}$, and hazelnut (scheme $6 \times 4$, irrigation) - 337,2. A significant part of the expenses is formed by fertilizers and pesticides $(37,4 \%$ and $31,1 \%$ of the cost, respectively), amortization $(21,8 \%$ and $22,1 \%)$ and fuel $(14,8 \%$ and $15,5 \%)$. For medium and small commodity producers the high capital intensity of mechanization in growing and automated lines of fruits processing is a significant investment barrier.

The absence of an industry fund for investing in the development of nursery farming, the creation of industrial orchards and the cultivation of nuts, the organization of deep processing of fruits, and the establishment of sales channels. Now in Ukraine is only interest-free lending at the expense of the state fund for supporting farms. In 2016 any farm could receive 250 thousand UAH for 5 years. In total 15 million UAH have been allocated for walnut farming, which can be provided only by 60 farms. But in many countries the sector is supported by various mechanisms: budget allocations (China, Georgia, Bulgaria, Turkey), intra-sector investment funds (French 
cooperatives), preferential lending to producers (EU countries), attraction of funds through trade taxation (Moldova).

Sluggish development of insurance in case of damage or death of crops (orchards) is caused by a number of factors, the main ones being ignorance and mistrust of the insurance industry, poor understanding of risk management mechanisms, high cost of insurance services, frequent non-compliance with agrotechnical production requirements, difficulty in assessing damage, untimely and incomplete payment of compensation. This encourages the activation of state support in the field of agricultural insurance, including by compensating part of the cost of policies, as well as improving insurance mechanisms and disseminating among farmers understanding of the effectiveness of risk diversification.

Inadequate level of scientific support of commodity nut cultivation in Ukraine. First of all, it concerns the improvement of technologies for vegetative reproduction of domestic varieties, the rationale for effective types of gardens, technologies for their creation and maintenance, high productivity, and post-harvest processing of nuts. Scientific support also requires the cultivation of rare but promising crops (chestnut, pistachio, pecans) for assortment, reproduction, creation and use of plantations, storage and processing of fruits.

Limited government support. In many countries with a suitable climate for growing nuts, which are characterized by high consumer demand, state levers stimulate the industry development. This is manifested in the creation of the most favorable regulatory and legal framework (Turkey, Moldova), the approval of state programs (Kyrgyzstan, Kazakhstan, Bulgaria, China), the introduction of effective mechanisms for raising funds and investing in production (Moldova, EU countries), providing soft customs transfer (Turkey, EU), promotion of healthy nutrition (Japan, Western Europe, USA). In Ukraine state support for the industry is insignificant. In 2016 year it was limited by interest-free loans for area of 50 ha.

\section{Conclusions}

The nutritional value of nuts, the weighty external demand and the presence of competitive advantages of our country impels us to overcome the identified counterbalances and expand domestic production.

\section{Bibliography}

1. Egorov B. Stan harchuvannja naselennja Ukraïni // Tovari i rinki. - 2011. - №1. - S. 140-147.

2. Zatokovij F.T. Novi bukovins'ki sorti i formi goriha grec'kogo / F.T. Zatokovij, L.F. Satina, // Sadivnictvo: mizhv. nauk. tem. zb. / In-t sad-va UAAN. - Kiïv: SPD «Zhitelev S.I.», 2009. - Vip. 61. - S. 116-121.

3. Zatokovoj F.T. Promyshlennaja kul'tura greckogo oreha /, L. F. Satina, V. I. Sajko, M. K. Joltuhovskij. - Kiev: Urozhaj, 1986. $-96 \mathrm{~s}$.

4. Salo I.A. Osnovni tendenciï rozvitku rinku gorihoplidnih v Ukraïni ta sviti / I.A. Salo // Problemi ekonomiki. 2012. - №4. - S. 9-12.

5. Satina G.M. De lipshe saditi gorihovi sadi? Zonal'ne rozmishhennja gorihoplidnih nasadzhen' / G.M. Satina, I.S. Kosenko, M.€. Opanasenko // Sad, vinograd i vino Ukraïni. - 2014. - №4-6. - S. 4-6.

6. Satina G.M. Naukovi osnovi ta skladovi galuzevoï programi rozvitku gorihivnictva v Ukraïni / [G. M. Satina, F. G. Oleshhenko, N. M. Koshlakova ta in.]. - Kiïv: Logos, 2011. - 100 s.

7. Satina G.M. Sortiment gorihoplidnih kul'tur Ukraïni / G.M. Satina, I.S. Kosenko, I.G. Chernobaj, L.F. Satina // Sad, vinograd i vino Ukraïni - 2014. - №10. - S. 8-9. Brozik S. Mandula/ Brozik Sandor, Kallay Tamasne, Apostol Janos. - Budapest: Mezo gazda, 2003. - 140 p.

8. Brozik S. Mandula/ Brozik Sandor, Kallay Tamasne, Apostol Janos. - Budapest: Mezo gazda, 2003. - 140 p.

9. Global Statistical Review 2014-2015: Nut and Dried Frut - Spain: INC, 2016. - 76 p.

10. Szentivanyi P. Dio / Szentivanyi Peter, Kallay Tamasne. - Budapest: Mezo gazda, 2006. - 204 p. 